\title{
Study on the Prevalence of Beta Haemolytic Streptococcus Among School Children
}

\author{
Manandhar $\mathrm{A}^{1}$, Shah $\mathrm{Y}^{2}$, Shrestha $\mathrm{J}^{3}$ \\ ${ }^{1}$ Ms. Anju Manandhar, M.Sc. Medical Microbiology, \\ Research Student, Kathmandu College of Science \\ and Technology, Kalimati, Kathmandu, Nepal, ${ }^{2} \mathrm{Mr}$. \\ Yogendra Shah, M.Sc. Medical Microbiology, Research \\ Associate, Everest International Clinic and Research \\ Center, Kalanki, Kathmandu, Nepal, ${ }^{3} \mathrm{Ms}$. Jyotsna \\ Shrestha, M. Sc. M L T Microbiology, Consultant Medical \\ Microbiologist, Department of Pathology, Bir Hospital \\ and Kathmandu Clinic, Kathmandu, Nepal.
}

\section{Introduction}

B eta haemolytic streptococci (BHS) have been recognized as pathogens causing a wide variety of disease states. Group A Streptococcus (GAS) consists of a single species, Streptococcus pyogenes ${ }^{1}$. It belongs to Lancefield group A and is beta-hemolytic, hence called Group A beta-hemolytic Streptococci (GABHS) ${ }^{2}$. It is a common pathogen of the upper respiratory tract. The pathogenesis of GAS is mediated by a variety of factors. One of them is Streptolysin ' $O$ ' toxin, which damages cell membranes and accounts for the hemolysis demonstrated on sheep blood agar ${ }^{1}$.

GAS is commonly associated with acute bacterial pharyngitis, as well as the cutaneous infections, impetigo and necrotizing fasciitis. Long-term, non-suppurative complications associated with untreated or recurrent infections include rheumatic fever (RF), rheumatic heart disease (RHD) and acute glomerulonephritis (AGN). It also causes peritonsillar abscess (quinsy), scarlet fever, erysipelas, puerperal sepsis, septicemia \& toxic shock syndrome ${ }^{3}$.

In developing countries, pharyngo-tonsillitis caused by BHS remains an endemic disease with annual incidence ranging from $100-200$ per 10,000 school children and is a major cause of cardiovascular mortality. $\mathrm{RF}$ is reported to occur in 1-3\% of streptococcal throat infections of children living in underprivileged condition ${ }^{4}$.

In Nepal, control programs for streptococci does not exist, moreover, such programs are not even in the

\footnotetext{
Address for correspondence

Ms. Anju Manandhar

Kathmandu College of Science and Technology,

Kalimati, Kathmandu, Nepal.

E-mail: manandhar_anju@yahoo.com
}

\begin{abstract}
Introduction: Beta haemolytic streptococcal infections have a worldwide distribution among children and it poses an important health problem globally. So, a five months study was conducted to know the prevalence of beta haemolytic streptococci (BHS) in the throat of school children. Materials and Methods: Throat swabs from 200 school children of Kirtipur were collected, transported to the laboratory and were processed for BHS following standard microbiological procedures. Group A Streptococci (GAS) were identified by beta haemolytic colonies, bacitracin sensitivity and catalase negativity test. ASO test was also performed from serum samples. Result: Altogether $18(9 \%)$ BHS isolates were identified from 200 samples, out of which $11(5.5 \%)$ isolates were from males and 7 (3.5\%) were from females. Among the $18 \mathrm{BHS}$ isolates, 10 were identified as GAS isolates. The number of GAS presented only $5 \%$ of total sample. There was no significant sex difference in colonization of GAS ( $p>0.05$ ). Majority of cases were asymptomatic. All GABHS isolates were sensitive to Penicillin. In Serological examination, i.e. Antistreptolysin O (ASO) titre, all serum samples showed less than 200 IU ASO titre. Conclusion: This result highlights the current situation of GABHS throat infection in school children of Kirtipur.
\end{abstract}

Key words: ASO, Bacitracin, BHS, GABHS, Streptococcus pyogenes.

row. Little information is known about the prevalence of $S$. pyogenes from the throat swab of school children in $\mathrm{Nepal}^{5}$. Hence this study was conducted with aims to explore the current situation about the prevalence of streptococcal carriage in the throat of school children.

\section{Materials and Methods}

\section{Sample collection}

Throat swabs of 200 school children within age limit of 3-6 years were collected for the purpose of the study

\section{How to cite this article?}

Manandhar A, Shah Y, Shrestha J. Study on the Prevalence of Beta Haemolytic Streptococcus Among School Children. J Nepal Paediatr Soc 2013;33(1):45-47. 
during December 2010 to April 2011. Verbal informed consent was obtained from school principals, parents and students before sample collection. During sample collection precautions were taken by wearing gloves, laboratory coat, and mask. Then, in a good light source tongue was kept down with a tongue depressor, a sterile cotton wool swab was rubbed vigorously over each tonsil, arch of the soft palate. Each sample was labeled with code number, age, sex, etc were also recorded. The sample was transported to the laboratory of Kathmandu Clinic within 2 hours of sample collection for processing as standard microbiological procedures ${ }^{6,7,8}$.

\section{Sample processing}

As soon as the samples were brought to the laboratory, they were cultured on blood agar plates and incubated at $37^{\circ} \mathrm{C}$ for 24 hours using $\mathrm{CO}_{2}$ jar. The plates were observed for the presence of small sized $(0.6-1 \mu \mathrm{m})$, typically matt or dry colonies surrounded by a clear wide zone (2-4 mm wide) of $\beta$ - haemolysis ${ }^{8}$. Following 24 hours of incubation, the tops of each suspected colonies of similar appearance to be tested were touched with a sterile straight wire in order to prepare the inoculums from the primary culture plate. Bacitracin disc was placed on the inoculated plate using a sterile forceps. Similarly Penicillin was also placed for sensitivity test. The plates were incubated at $37^{\circ} \mathrm{C}$ in $\mathrm{CO}_{2}$ jar for 24 hours. Following incubation, the appearance of a zone of inhibition surrounding the Bacitracin disc is indicative of GAS.

Further serological tests were also done. Serum samples from $18 \mathrm{BHS}$ positive students as well as 18 BHS negative students were collected with the help of a nurse and the collected samples were taken to the laboratory for ASO slide agglutination test.

\section{Results}

Out of 200 throat swabs studied, BHS was isolated from 18 samples (9\%). Among the isolates, 11 (5.5\%) were from male whereas $7(3.5 \%)$ were from female. Similarly, out of $18 \mathrm{BHS}$ isolates, 10 isolates were GABHS which comprises $6(3 \%)$ males and $4(2 \%)$ females. There was no significant sex difference in colonization of GABHS ( $p>0.05$ ) among 3-6 years school children. All the isolates were $100 \%$ sensitive to penicillin. In serological examination of serum samples with ASO slide agglutination test, all serum samples showed negative agglutination with ASO test.

\section{Discussion}

Group A beta-haemolytic streptococcal infection is one of the most common bacterial disease in human being. Treatment and prevention of dangerous complications in this disease is of great importance. According to different studies GAS is more commonly seen in children's pharynx comparing to that of adults. The results of this study are comparative with several similar studies conducted in different developing countries. Prasad et $a^{/}$reported $9.9 \%$ prevalence of BHS among school children of Nepal. A study conducted by Sevinc et $a /^{10}$ in (1-6) years healthy Turkish children reported $3.2 \%$ BHS. Another study by Devi et a/11 reported $7.7 \%$ BHS in Assam. Similar study conducted by Bhattarai et a/ ${ }^{12}$ in asymptomatic Nepalese children found $4.8 \% \mathrm{BHS}$. Another study of Martin et $\mathrm{a} /{ }^{13}$ showed $15.5 \%$ BHS. Braito et al ${ }^{14}$ also reported $27.6 \% \mathrm{BHS}$ in his study. Lloyd et a/15 also reported $21.4 \%$ BHS in schoolchildren of Chennai.

In case of GABHS, a study done by Gurung et $a l^{16}$ in paedriatic patient of Kathmandu found 5\% GABHS. Martin et $\mathrm{a}^{13}$ also found $5 \%$ GABHS. However several other investigators reported higher GABHS prevalence rate. Dumre et $a^{17}$ and Rijal et $a^{5}$ found $10.9 \%$ and $9.2 \%$ GABHS respectively in their studies. Similarly Durmaz et $a /^{18}$ also reported the prevalence of $S$. pyogenes nasopharyngeal carriage in $14.3 \%$ healthy school children and children in an orphanage in Turkey. GAS was found to be only $1.08 \%$ in asymptomatic Nepalese school children of public school as reported by Bhattarai et $a l^{12}$ in his study. But, Betriu et $a /^{19}$ observed that the prevalence of GABHS was significantly greater $(40.47 \%)$ among children of pre-school age (4-6 years).

In serological test, all 36 serum samples were ASO non-reactive it means that ASO content in the serum was less than $200 \mathrm{IU} / \mathrm{mL}$. When the serum sample and latex reagent was thoroughly mixed, it remained in homogenous suspension. If the suspension had developed agglutination then it can be said the individual was infected by $S$. pyogenes. Increased serum antibody titers to streptolysin O (ASO) are usually indicative of recent streptococcal infection not active rheumatic fever.

Table 1: Isolation of BHS and GABHS from school children

\begin{tabular}{|c|c|c|c|c|c|c|c|c|c|}
\hline \multirow{3}{*}{ Gender } & \multicolumn{4}{|c|}{ Positive BHS } & \multirow{2}{*}{\multicolumn{2}{|c|}{$\begin{array}{l}\text { Total } \\
\text { BHS }\end{array}$}} & \multirow{2}{*}{\multicolumn{2}{|c|}{$\begin{array}{c}\text { Negative } \\
\text { BHS }\end{array}$}} & \multirow{3}{*}{ Total } \\
\hline & \multicolumn{2}{|c|}{ GABHS } & \multicolumn{2}{|c|}{ Non GABHS } & & & & & \\
\hline & $\mathrm{n}$ & $\%$ & $\mathrm{n}$ & $\%$ & $\mathrm{n}$ & $\%$ & $\mathrm{n}$ & $\%$ & \\
\hline Male & 6 & 3 & 5 & 2.5 & 11 & 5.5 & 111 & 55.5 & 122 \\
\hline Female & 4 & 2 & 3 & 1.5 & 7 & 3.5 & 71 & 35.5 & 78 \\
\hline Total & 10 & 5 & 8 & 4 & 18 & 9 & 182 & 91 & 200 \\
\hline
\end{tabular}


Ozturk et al ${ }^{1}$ found that among 91 GAS carriers, $37 \%$ student has elevated ASO ( $\geq 200 \mathrm{IU} / \mathrm{ml}$ ) but among non carriers only $0.3 \%$ student had elevated ASO. Dewasy et $a^{20}$ found the highest rate of ASO antibody in the age group (10-20) years $(23.40 \%)$

\section{Conclusion}

In conclusion, the finding of the present study highlights that the children of (3-6) age group can also be infected by S. pyogenes. The occurrence of BHS and GABHS infection among school children was found to be $9 \%$ and $5 \%$ respectively out of 200 throat specimens collected. All GABHS isolates were $100 \%$ susceptible to penicillin. Empirical treatment of clinical pharyngitis with penicillin is very common in general practice.

Acknowledgements: Authors would like to acknowledge the Principal, teachers, parents, school children of all participating schools and the staffs of Bir Hospital/ Kathmandu Clinic for their help throughout the research period. We expressed our gratitude to Mr. Dhan Kumar Pant for reading the manuscript.

Funding: None

Conflict of Interest: None.

Permission from IRB: Yes

\section{References}

1. Ozturk CE, Yavuz T, Kaya D, Yucel M. The rate of asymptomatic throat carriage of group $A$ streptococcus in school children and associated ASO titers in Duzce Turkey. Jpn J Infect Dis 2004;57:271-72.

2. Ananthanarayan R, Paniker CKJ. Textbook of Microbiology. $6^{\text {th }}$ ed. Oreint Longman press: India; 2000.

3. Todar K Todar's Online Textbook of Bacteriology. University of Wisconsin, Department of Bacteriology. 2008. www.textbookofbacteriology.net Accessed; $10^{\text {th }}$ February 2013

4. Shrestha L, Khattri JBK, Brahmanathan KN, Nagra JS. Prevalence of streptococcal pharyngitis among school children of Pokhara valley. Nepal. J Nepal Med Assoc 2002;41(141):253-57.

5. Rijal KR, Dhakal N, Shah RC, Timilsina S, Mahato P, Thapa S, Ghimire P. Antibiotic susceptibility of group A streptococcus isolated from throat swab culture of school children in Pokhara, Nepal. Nepal Med Coll J 2009;11(4):238-40.

6. Collee JG, Marmion BP, Fraser AG et al. Mackie and McCartney Practical Medical Microbiology. $14^{\text {th }}$ ed. Churchill Living stone: United Kingdom; 1996.

7. Forbes BA, Sahm DF, Weissfield AS. Bailey and Scotts's Diagnostic Microbiology. $12^{\text {th }}$ ed. Sydney M Finegold, Baltimore: Mosby; 1990.
8. Vandepitte $\mathrm{J}$ and Verhaegen J, Engbaek K, Rohner P, Piot P, Heuck CC. Basic Laboratory Procedures in Clinical Bacteriology. $2^{\text {nd }}$ ed. WHO, Geneva, Switzerland: 2003. pp 60-65,103-136.

9. Prasad R, Bhattarai H, Guragain RPS. Beta hameolytic streptococci in the throat of asymptomatic Nepalese school children. J Inst Med 1990;12:1-9.

10. Sevinc I, Enoz M. The prevalence of group A betahemolytic streptococcus in healthy Turkish children in day-care centers in Ankara. Chang Gung Med J 2008;31(6):554-58.

11. Devi U, Borah PK, Mahanta J. The prevalence and antimicrobial susceptibility patterns of betahemolytic streptococci colonizing the throats of schoolchildren in Assam, India. J Infect Dev Ctries 2010;5(11):804-808.

12. Bhattarai TN, Shrestha UK. Prevalence of streptococcal throat infection in school children. Souvenir (AProceedings of Bir Hospital Publication). 1995; pp 87-91

13. Martin JM, Green M, Barbadora KA, Wald ER. Group A streptococci among schoolaged children: clinical characteristics and the carrier state. Pediatrics 2004;114:1212-19.

14. Braito A, Galgani I, Mohammed MR, lozzi C, Ame SM, Haji HS, Zanchi A. Epidemiology of streptococcus group $A$ in school aged children in Pemba. East Afr Med J 2004;81(6):307-12.

15. Lloyd CAC, Jacob SE, Menon T. Pharyngeal carriage of group A streptococci in school children in Chennai. Indian J Med 2006;124:195-98.

16. Gurung R, Budhathoki S, Amatya R, Poudyal N, Shrestha S, Baral R. Group A beta haemolytic streptococcus infection presenting with sore throat at paediatric OPD. Health Renaissance 2010;8(2):90-92.

17. Dumre SP, Sapkota K, Adhikari N. Asymptomatic throat carriage rate and anti microbial resistance pattern of Streptococcus pyogenes in Nepalese children. Kathmandu Univ Med J 2009;7(4):392-96.

18. Durmaz R, Durmaz B, Bayraktar M, Ozerol IH, Kalcioglu MT, Aktas E, Cizmeci Z. Prevalence of group A streptococcal carriers in asymptomatic children and clonal relatedness among isolates in Malatya, Turkey. J Clin Microbiol 2003;41:5285-87.

19. Betriu C, Romero J, Sanchez A, Gomez M, Picazo JJ, Sanchez ML. Carrier state of groups A, B, C and D beta haemolytic streptococci. Enferm Infec Microbial Clin 1994;12(10):483.

20. Dewasy BL, Singh YI, Jha BK, Kapil J. A rapid screening test by the latex antistreptolysin $O$ test for streptococcal infections in CMS Teaching Hospital, Bharatpur, Nepal J Coll Med Sci 2010;6(2):26-28. 